\title{
PROCESS MANAGEMENT IN THE REGIONAL LIBRARIES
}

\author{
[Procesní management v krajských knihovnách] \\ Lea Prchalová ${ }^{1}$ \\ ${ }^{1}$ Mendelova univerzita v Brně, Provozně ekonomická fakulta, Zemědělská 1, 61300 Brno \\ Email: prchalova@svkos.cz
}

\begin{abstract}
The aim of this article is to start process management of regional libraries. On the basis of an inquiry it was verified, that there is no application of this type of management in regional libraries and the principles of process management are not known sometimes. Visions and derived strategic goals are very close among regional libraries, their realisation is however connected with many factors. The most important of them are the space possibilities. In this article there are mentioned reasons and need of process attitude towards library management. You can find here a tree structure of processes of regional libraries and a description of a process of Czech monographies acquisition. The article finishes with phases of realisation of process management.
\end{abstract}

Keywords: library services, process management, regional libraries, standards, tree structure of processes.

\section{JEL classification: M11}

Doručeno redakci: 4.10.2013; Recenzováno: 2.5.2014; 2.5.2014; Schváleno k publikování: 23.9.2014

\section{Úvod}

Procesní princip je všeobecně akceptován a vyžadován ve veškerých oblastech komerčních aktivit, at' již ve výrobě či při poskytování služeb, ale též v oblastech veřejné správy, např. všeobecně přijímaný model CAF (Zlepšování organizací veřejného sektoru, 2013).

„Proces - soubor vzájemně souvisejících nebo vzájemně působících činností, které přeměňují vstupy na výstupy.

Procesní prŕístup - systematická identifikace a management procesů používaných v organizace a zejména jejich vzájemné působení“ (ČSN EN ISO 9000, 2006).

Dle ČSN EN ISO 9000 je definováno osm zásad managementu kvality, které jsou zapotřebí k zvyšování výkonnosti organizace. Jednou z nich je právě procesní př́stup. Dále se jedná o principy:

- Zaměření na zákazníka,

- Vedení a řízení lidí (vůdčí role),

- Zapojení lidí,

- Systémový př́stup k managementu,

- Neustálé zlepšování,

- Přístup k rozhodování zakládající se na faktech,

- Vzájemně prospěšné dodavatelské vztahy.

Zmíněná norma uvádí rovněž výčet úkolů, které jsou zapotřebí pro zavedení, udržování a zlepšování řízení organizace tak, aby bylo dosaženo zvýšené spokojenosti všech zainteresovaných stran. K těmto činnostem patří určování potřeb a očekávání zákazníků jiných zainteresovaných stran, definice procesủ a stanovování odpovědnosti, zavádění metod měření efektivnosti a účinnosti každého procesu, nastavení nástrojů k zabránění vzniku neshod mezi plánovanými veličinami a realitou, nastavení způsobů odstraňování jejich př́ččn apod. 
Problematika procesního přístupu $\mathrm{k}$ řízení knihoven není bohužel př́liš publikována. Autoři S. Laughlin a R. W. Wilson (2008) spatřují největší přínos procesního řízení pro knihovny v nasměrování činností knihovny dle výsledků analýzy uživatelských požadavků a přesného porozumění jejich způsobu práce. Uživatelé vyžadují přesné informace, které jsou nabízeny různým způsobem dle stupně informační gramotnosti zájemce (často jde o služby s asistencí). Je nutno dbát na rychlost vyřizování požadavků, zcela běžně jsou požadovány služby 24/7, tj. nepřetržitě. Poměrně novou záležitostí je požadavek na osobní zaměření služeb spočívající např. v průběžné informovanosti o nových publikacích oblíbených autorů, a to knihovníkem hovořícím jazykem uživatele. Je vyžadován věrohodný servis na stejné úrovni bez ohledu na hodinu vyřizování požadavku či zda se jedná o osobní nebo elektronický kontakt. Neméně důležité je také prostř̌edí, v němž je služba nabízena; tedy na větším významu nabývají dostatečné a př́ijemné prostory knihoven.

V návaznosti na výsledky analýzy je nutno stanovit klíčové a podpưrné procesy, kde je za velmi př́nosné považováno shromažd’ování a sdílení informací $\mathrm{k}$ realizaci cílů procesů. Mezi argumenty podporující procesní řízení také figuruje odstranění izolovanosti činností a hledání společných řešení ke zlepšování běžných aktivit knihovny. Samotní zaměstnanci popisují další prrínos ve zmírnění frustrace z možných chyb při odstraňování problémů bez týmové komunikace.

Zajímavým př́ikladem může být též zkušenost $\mathrm{z}$ univerzitní knihovny v Arizoně. Ch. Pintozzi (2014) popisuje významné výkonnostní posuny díky využívání principů Total Quality Managementu včetně procesního principu. Základními pilíŕi se stala orientace na spokojenost zákazníků (nejen uživatelů knihovny), týmová práce, stanovení odpovědnosti a pravomocí a neustálé zlepšování. Odpovědnost za respektování principů managementu kvality a sledování kvality je rozprostřena na všech úrovních řízení knihovny.

\section{Krajské knihovny}

V České republice existuje 14 knihoven, které mají ze zákona č. 257/2001 Sb., o knihovnách a podmínkách provozování veřejných knihovnických a informačních služeb (knihovního zákona), funkci krajských knihoven. Jedná se o instituce působící ve veřejném zájmu, které poskytují vzdělávací a kulturní služby. Zřizovateli knihoven jsou jednotlivé kraje s výjimkou Moravské zemské knihovny v Brně, která je zřizována Ministerstvem kultury. Knihovny vznikaly $\mathrm{v}$ různých obdobích, byly zřizovány různými subjekty a měly také odlišné funkce. $\mathrm{Z}$ dnešních krajských knihoven působily v roli vědeckých knihoven od začátku své existence knihovny v Brně, Hradci Králové, Olomouci, Ostravě a Plzni. Další knihovny plnily později funkce městských i vědeckých knihoven, např. v Českých Budějovicích či Kladně. Po vzniku krajů došlo $\mathrm{v}$ důsledku změn zřizovatelů k rozvinutí rolí bývalých státních vědeckých knihoven a ke zrrízení dalších krajských knihoven, např. v Pardubicích, ve Zlíně či Karlových Varech.

Aktivity krajských knihoven, at’ se již jedná o původní vědecké knihovny nebo nikoliv, jsou dnes do značné míry shodné a jejich poslání lze vymezit následovně:

- uspokojování informačních potřeb studujících,

- poskytování informačního zázemí k celoživotnímu vzdělávání občanů,

- podpora společenského a hospodářského rozvoje kraje prostřednictvím informačních služeb,

- uchovávání kulturního dědictví kraje, mapování regionálních informačních zdrojů a jejich digitalizace,

- nabídka literatury a služeb k realizaci volnočasových aktivit občanů a návštěvníků kraje, 
- podpora činnosti malých knihoven ve smyslu vyrovnávání podmínek pro veřejné knihovnické a informační služby.

Vize krajských vědeckých knihoven úzce souvisí s prostorovými možnostmi, které se $\mathrm{u}$ jednotlivých knihoven velmi liší, a realizace změn $\mathrm{k}$ lepšímu v tomto směru většinou není v silách samotného managementu knihoven. Pokusíme-li se od této skutečnosti oprostit, můžeme za vizi prohlásit následující text:

„Poskytování knihovnických a informačních služeb v požadované kvalitě ochotnými knihovníky a knihovnicemi $\mathrm{v}$ prŕjjemném prostředí, a to bezplatně nebo za symbolické poplatky.“

Ve strategii k naplňování vize by měla být zakotvena řada strategických cílů s různými prioritami, např. poskytování informačních služeb, zejména zpracování rešerší z databází různých vědních oborů, online př́stup uživatelů z domova či zaměstnání ke vzdáleným elektronickým zdrojům, služby uživatelům se speciálními potřebami, retrospektivní bibliografické zpracování dokumentů vztahujících se kdanému kraji, digitalizace regionálních fondů apod. U všech cílů je samozřejmě třeba definovat kvantifikovatelná kritéria a jejich požadované hodnoty, které budou následně sloužit k posuzování míry naplnění strategických cílů v procesech knihoven.

Tento prŕspěvek vychází $\mathrm{z}$ předpokladu, že se procesní řízení v knihovnách neaplikuje a povědomí o metodách a technikách je velmi slabé. Změnu situace mohou přinést dvě oblasti:

- zlepšení znalostí o skutečném obsahu a významu pojmů a principů;

- návod, jak tyto znalosti aplikovat v praxi, tj. zlepšení kompetencí manažerů a následně dalších zaměstnanců knihoven.

Nabízí se zde možnost obrátit se na univerzitní prostředí, využít teoretické poznatky odborníků a skloubit je s potřebou pragmatické aplikace v knihovnách. Této problematice bude také věnována disertační práce autorky, jejíž odborný přínos bude spočívat v návrhu aplikovatelného modelu procesního řízení a naplnění konkrétních manažerských požadavků. Tento článek je jedním z dílčích kroků v rámci zpracovávání výše zmíněné disertační práce a jeho cílem je navrhnout klíčové řídicí prvky vybraného subprocesu krajské knihovny a identifikovat základní kroky pro realizaci procesního modelu řízení knihovny.

\section{Současný stav řešené problematiky}

Při procesním pojetí nejsou zvenčí nařízeny aktivity, nejsou nastaveny závazné limity, jako tomu bylo např. u normy ISO řady 9000. Organizace vycházející z požadavků všech zainteresovaných stran si samy definují své procesy a vazby mezi nimi. Vlastní procesní model dává návod na definici elementárních činností a vazeb, čímž napomáhá knihovně jednoznačně identifikovat požadované výstupy procesů a odvozovat potřebné vstupy. Tím, že každý proces musí být ř́zen, je organizace přinucena stanovit smysluplné metriky, jejichž vyhodnocování slouží k řízení procesu.

Identifikací elementárních činností dle analýzy uvnitř organizace je nastavena vazba na odpovídající a nutné kompetence zaměstnanců, tj. na jejich znalosti a dovednosti potřebné $\mathrm{k}$ takto definované elementární činnosti. 
S požadavkem na řízení každého procesu je jednoznačně spojena úloha procesu zlepšování (managementu změny), který je subprocesem každého procesu v prrípadě identifikace významné odchylky v každém kontrolním bodě.

Procesní model tím, že klade důraz na vazby mezi procesy, pomáhá identifikovat problémová či krizová místa organizace. Ve spojení s osmikrokovou metodikou managementu změny (Audit jakosti, 1998) a především s využitím týmové práce napomáhá k odstraňování krizových či k zlepšení slabých míst v aktivitách knihovny a k zefektivnění celkové činnosti.

Metodiku managementu změny, který umožňuje řešení problémů v osmi krocích, je vhodné zaznamenávat do standardizovaných formulářù (G-8D Report, 2013). Jde o tyto fáze řešení problému:

- identifikace problému a náprava (okamžitý zásah k eliminaci problému),

- sestavení řešitelského týmu,

- redefinice problému v týmu,

- identifikace př́čin problému,

- návrh nápravných opatření, stanovení efektivnosti a účinnosti,

- výběr nejlepšího řešení, jeho standardizace,

- zobecnění řešení do preventivních opatření,

- odměna týmu.

\section{Úloha mezinárodních norem ISO řady 9000}

Procesní př́stup je standardizován v mezinárodních normách ISO řady 9000 od roku 2000 a úzce souvisí s pojmem kvalita. Verze normy ISO 9001 byla od svého počátku strukturována, chápána a interpretována jako soubor dvaceti více méně izolovaných požadavků, čemuž v praxi odpovídalo dvacet izolovaných firemních směrnic a jedna príručka kvality jako zastřešující dokument. Při izolované aplikaci dozorované třetími stranami a poradenskými firmami však docházelo k formalizmu, který nezaručoval efektivní řízení organizace. Teprve verze z roku 2000 se důsledně přiklonila k procesnímu pojetí a striktně vyžaduje definovat aktivity organizace na procesním principu. Aktuálně je platná novela normy mezinárodní norma EN ISO 9001:2008 (ČSN EN ISO 9001, 2010).

Tomuto pojetí předcházel vývoj př́istupu k řízení organizace v 80. a 90. letech, který byl zachycen nejen v normách ISO řady 9000, nýbrž především v zákaznických modelech vyplývajících z dodavatelsko-odběratelských vztahů. Obsah pojmu kvalita (ČSN EN ISO 9000, 2006) se posunul od původního vnímání ve smyslu souboru požadavků na fyzikálnětechnické parametry výstupního produktu definované pouze zákazníkem k stávající definici, podle níž je kvalita vnímána jako stupeň splnění libovolného požadavku zainteresovaných stran (ČSN EN ISO 9001, 2010). Současně došlo k posunu od statického popisu aktivit organizace pomocí mnohdy byrokraticky izolovaných směrnic k procesnímu pojetí, které klade důraz na vzájemnou provázanost jednotlivých činností a především na schopnost organizace včas identifikovat potřebu změny a na tuto potřebu změny efektivně zareagovat. Nový přístup zohledňuje nejen zákaznické požadavky, ale i požadavky dalších zainteresovaných stran, a tím umožňuje vytvořit jednotný systém integrovaného managementu organizace, který je navíc aplikovatelný nejen v podnikatelském sektoru (výrobních sférách i službách), ale má zcela univerzální použití pro libovolnou oblast lidských aktivit, tedy i v organizacích neziskového sektoru či v organizacích silových složek (Grasseová, 2008). 
Současný vývoj strategického řízení firem a jednoznačná orientace na procesní pojetí v souladu s mezinárodními standardy ISO řady 9000 pronikají do univerzit, středních škol a dalších vzdělávacích institucí, mezi které bezesporu patří knihovny, především vědecké, vysokoškolské či ústřední knihovny rezortů (Busch, 2008).

Stávající standardy pro poskytování služeb knihovnám, měření výkonů

Ke sledování výkonů, které se promítají do kvality poskytovaných služeb, slouží v knihovnách několik dále popsaných systémů a metod.

Celostátně sledované statistické ukazatele výkonu knihoven jsou shromažd'ovány a vyhodnocovány na základě zákona č. 89/1995 Sb. o státní statistické službě, ve znění pozdějších předpisů. Garantem za státní statistickou službu za celou oblast kultury, kam spadají též krajské vědecké knihovny, je Národní a poradenské středisko pro kulturu (NIPOS), útvar Centrum informací a statistik kultury (CIK). Sledované statistické ukazatele vykazované prostřednictvím KULT (MK) 12-01 se mění v návaznosti na vývoj knihovnických služeb občanům. V současné době je sledováno cca 130 ukazatelů v následujících kategoriích: knihovní fond, uživatelé, výpůjčky, meziknihovní výpůjční služby a výměnné fondy, kulturní akce, vzdělávací akce, publikační činnost, vybavení knihovny studijními místy, elektronické služby, struktura zaměstnanců knihovny, vybrané ekonomické ukazatele, atd.

Benchmarking je dalším užívaným nástrojem řízení, který prostřednictvím měření výkonů a procesů $\mathrm{v}$ knihovnách a jejich systematického porovnávání $\mathrm{s}$ výkonem ostatních hledá nejlepší řešení. Umožňuje manažerům knihoven sdílení zkušeností mezi srovnatelnými knihovnami a identifikaci příležitostí ke zlepšení výkonů. V prostředí českých knihoven, které využívají princip učící se organizace, je aplikován od roku 2005. Dosud je k tomu účelu užíván systém 29 ukazatelů členěných do tří skupin:

- Podmínky pro činnost knihovny, např. podíl financování knihovny na rozpočtu obce, objem knihovního fondu na 1000 obyvatel, procento obnovy knižního fondu, počet zaměstnanců (úvazků) na 1000 obyvatel.

- Uživatelé, služby, např. registrovaní čtenáři - procento z obsluhované populace, registrovaní čtenáŕi do 15 let - procento z obsluhované populace, počet návštěv na jednoho obyvatele, obrat knihovního fondu.

- Financování, výdaje, účinnost - celkové provozní náklady v přepočtu na jednoho obyvatele, náklady na pořízení knihovního fondu $\mathrm{v}$ přepočtu na jednoho obyvatele, Procento nákladů na pořízení knihovního fondu z celkových provozních nákladů.

Mezi krajskými vědeckými knihovnami v ČR je však problém se srovnatelností, nebot' působí v sídlech s velmi rozdílným počtem obyvatel.

K měření kvality služeb lze rovněž užívat nástroj LibQUAL+®, jehož cíle spočívají:

- ve vypěstování výlučného postavení knihovnických služeb,

- v pomoci knihovnám, jak lépe porozumět uživatelskému vnímání kvality knihovnických služeb,

- v systematickém sběru a interpretaci zpětné vazby od uživatelů,

- ve vzájemné výměně hodnocení mezi srovnatelnými knihovnami,

- v nalezení nejlepších př́íkladů knihovnických služeb,

- v posílení schopnosti zaměstnanců knihoven využívat výsledky testů ve prospěch zlepšení služeb. 
Jedná se o testy, které byly z původního nástroje SERVQUAL (sestaveného v roce 2000 pro komerční sféru) upraveny pro prostředí knihoven. Podnět k př́pravě dala ARL (Association of Research Libraries) a později se k aplikaci a vývoji testů přidala organizace LIBER (Association of European Research Libraries). V současné době je užíván více než 1000 knihovnami v USA, Austrálii, Africe, Asii i v Evropě (např. ve Velké Británii, Nizozemí či Norsku.). Testovací nástroj se stal postupně součástí portálu, který knihovnám nabízí řadu služeb souvisejících s lepším pochopením uživatelských požadavků a kvalitou knihovnických služeb. V českém prostředí však není nástroj plošně aplikován, pravděpodobně proto, že sledování kvality není vyjma ukazatelů uvedených v celostátním statistickém výkazu pro knihovny povinné a asi též proto, že je při uživání nástroje nutno hradit provozní poplatky.

Pro zlepšování kvality knihovnických služeb byly na základě celostátního knihovnického konsensu podpořeného dotazníkových průzkumem připraveny v roce 2003 standardy veřejných knihovnických služeb, které byly v roce 2011 aktualizovány (Standard pro dobrou knihovnu, 2013). Aktualizace vycházela z naplňování standardů v praxi a ze zahraničních vzorů především v Německu a Velké Británii. Předmětem standardu, který je diferencován dle počtu obyvatel $v$ sídlech knihoven, je provozní doba knihovny, tvorba knihovního fondu, studijní místa a PC s internetem, elektronický katalog, provádění průzkumu spokojenosti uživatelů a další. Standard byl vyhlášen formou metodického pokynu Ministerstva kultury, přičemž vychází z Manifestu IFLA/UNESCO o veřejných knihovnách z roku 1994 a navazující směrnice IFLA: Služby veřejných knihoven z roku 2010. Standardy však nejsou primárně určeny krajským knihovnám.

Okrajově užívanými nástroji sloužícími pro řízení knihoven jsou také analýza nebezpečí a hodnocení rizik a SWOT analýza.

Soubor požadavků na procesní řízení musí vycházet $\mathrm{z}$ existujících modelů, které jsou zahrnuty např. v normě ISO řady 9000 či v americkém modelu filozofie TQM (Bhatt, 2012). Dále se lze inspirovat informačními zdroji týkajícími se modelu štíhlého podniku, modelu „správné praxe“ nebo modelu excelence a od něj odvozeného modelu CAF (Veselý 2013).

\section{Použitá metodika}

Prvním krokem řešení problému bylo mapování situace v krajských vědeckých knihovnách.

\section{Hypotéza: V krajských knihovnách na území České republiky není dostatečné povědomí o řízení knihoven na principech procesního pojetí.}

Do 13 krajských knihoven byl v srpnu 2013 zaslán elektronickou poštou krátký dotazník, jehož cílem bylo výchozí zmapování informovanosti managementu knihoven o procesním řízení, př́íp. o aplikaci procesního řízení v těchto institucích, a tudíž potvrzení či vyvrácení stanovené hypotézy. Vynechána byla Městská knihovna v Praze, která má specifické funkce a prioritně působí jako metropolitní knihovna. I když se počet 13 nejeví jako dostatečně rozsáhlý pro statistické šetření, jedná se o úplný, reprezentativní soubor krajských knihoven.

Konkrétní otázky a odpovědi jsou uvedeny v následujícím textu.

Otázka č. 1: Používáte k řízení knihovny (nikoliv k odborné knihovnické práci) mezinárodní standardy? Pokud ano, které (ČSN EN ISO 9001:2009, Evropský model excelence, Společný hodnoticí rámec CAF, jiné)?

Otázka č. 2: Aplikujete ve své knihovně model procesního řízení? 
Otázka č. 3: Znáte principy procesního managementu?

Otázka č. 4: Znáte pojem ,štíhlá“ organizace?

Otázka č. 5: Které z principů a technik, „štíhlé“ organizace jste v praxi aplikovali?

Otázka č. 6: Považujete v podmínkách Vaší knihovny uvedené standardy a techniky za potřebné?

Otázka č. 7: Považujete v podmínkách Vaší knihovny uvedené standardy a techniky za aplikovatelné?

Tabulka 1: Shrnutí odpovědí

\begin{tabular}{|c|l|}
\hline Č. otázky & Odpovědi \\
\hline 1 & 1 x Ano, částečně. 12 x Ne. \\
\hline 2 & 1 x Ano. 3 x Ano, částečně. 9 x Ne. \\
\hline 3 & $8 \times$ Ano, 5 x Ne. \\
\hline 4 & $7 \times$ Ano. 6 x Ne. \\
\hline 5 & \\
\hline 6 & $6 \times$ Ano. 6 x Ne. 1 x Nevím. \\
\hline 7 & $13 \times$ Ano. \\
\hline
\end{tabular}

Zdroj: vlastní zpracování

Shrnutí:

- Žádný z uvedených standardů není v krajských knihovnách využíván s výjimkou jednoho respondenta, který připouští částečnou aplikaci ČSN EN ISO 9001:2009. Jedná se však o dosti problematickou odpověd', nebot' tuto normu v podstatě nelze aplikovat částečně.

- Převážná většina procesní př́stup neaplikuje. U odpovědí „,̌ástečně“ lze vyjádřit pochybnost vzhledem k rozsahu př́stupu (zpracování základní stromové struktury procesů), resp. porozumění tomu, jak je př́stup jednotlivými managementy vnímán (uvedeno provedení analýzy zpracování knihovního fondu a optimalizace jedné zpracovatelské linky a částečné využívání technik). V případě kladné odpovědi $\mathrm{z}$ jedné knihovny nelze na základě znalosti prostředí vyloučit, že došlo k nesprávné interpretaci položené otázky.

- Je zajímavé, že přestože na otázku č. 3 a č. 4 odpověděla více než polovina knihoven kladně a jsou jim známy principy procesního prístupu i „štíhlé“ organizace, knihovny procesní př́stup $\mathrm{v}$ praxi neaplikovaly. Situace by si zasloužila hlubší rozbor jak ze znalostního tak z manažerského pohledu.

- Šest knihoven uvedlo, že aplikovaly principy „štíhlé“ organizace, a zmínilo metodiky $5 \mathrm{~S}$, týmové práce, PDSA a VSM. Je př́iznačné, že jsou zmiňovány dnes velmi populární metodiky „štíhlých“ organizací manažerského př́istupu poprvé aplikovaného firmou TOYOTA. Z porovnání odpovědí vyplývá praktická zkušenost z českého prostředí, v němž je minimálně využíváno technik procesního pojetí včetně odpovídajících nástrojů, ačkoliv právě procesní pojetí je jedním ze 4 základních principů „štíhlé“ organizace. Jednotlivé techniky sloužící k řešení problému jsou chápány izolovaně, a tudíž v důsledku nemusí být dostatečně efektivní.

- Ti, kteří procesní př́stup neznají, by neměli hodnotit aplikovatelnost a potřebnost. Přesto se tak ve čtyřech prŕpadech stalo, $\mathrm{z}$ toho třikrát respondenti uvedli nepotřebnost procesního př́ístupu. Při záporné odpovědi a neznalosti se zdá, že manažeři necítí vnější tlak na řešení problémů. Možné vysvětlení spočívá též ve skutečnosti, že v posledních dvou desetiletích došlo v „laickém“ povědomí k deformaci pojmů a rozšśřil se názor, že se jedná o zatěžující a nežádoucí techniky. Příčiny lze spatřit ve věcné neznalosti 
a v deformaci obsahu pojmů v praxi, kdy např. propuštění zaměstnanců (bez procesní analýzy) je prohlašováno za „zeštíhlení organizace“.

\section{Odpovědi třinácti dotázaných knihoven potvrdily stanovenou hypotézu, že se řízení na procesním principu nejen neaplikuje, ale ani povědomí o vhodných metodách a technikách pro tento styl řízení je velmi slabé.}

Po vyhodnocení dotazníků následoval další krok řešení problému, při němž byly identifikovány klíčové procesy krajské vědecké knihovny. $Z$ těchto procesů byl vybrán jeden, na kterém byly ilustrovány hlavní rídicí prvky procesu.

Na tomto základě bude postupně formulován obecný závěr směřující k identifikaci základních kroků v realizaci procesního př́stupu k řízení knihovny.

Změnu situace ohledně procesního přístupu v řízení knihoven mohou přinést dvě oblasti:

- zlepšení znalostí o skutečném obsahu a významu pojmů a principů;

- návod, jak tyto znalosti aplikovat v praxi, tj. zlepšení kompetencí manažerů a následně dalších zaměstnanců knihoven.

Nezbytným předpokladem je informovanost vedení organizace i zaměstnanců o důvodech připravovaných změn, správnosti jejich průběhu a prrínosech po realizaci.

Dílčí krok ke zlepšení v těchto oblastech nabízí též následující část příspěvku.

Př́iklad modelu procesního řízení v knihovně

Dále je uveden model založený na kombinace profesní dělby práce a s ní související struktury organizace $\mathrm{s}$ teoreticky čistým procesním pojetím chápaným jako transformace vnějších vstupů na vnější výstupy. Pragmatickým kompromisem se stalo přijetí stromové struktury založené na profesním základě (např. ekonomicko-provozní útvar, útvar zajišstování informačních zdrojů apod.) s tím, že tyto profesní aktivity jsou chápány jako nosné (klíčové) procesy knihovny, resp. subsystémy $\mathrm{v}$ rámci celé organizace.

Stromová struktura byla zvolena proto, že odpovídá realitě založené na profesní dělbě práce v českých knihovnách. Tato struktura je také nutná pro rozpracování cílů organizace.

Uvedený př́íklad stromové struktury nepředstavuje ani nemůže představovat co do typů procesů, jejich počtu a vazeb závaznou strukturu pro veškeré knihovny. Jedná se pouze o model. V praxi je zapotřebí tento model přizpůsobit souboru požadavků kladených na konkrétní knihovnu. Management knihovny musí sám stanovit, jak bude pro konkrétní soubor požadavků zainteresovaných stran tato struktura vypadat. Vazba na potřebu lidských zdrojů pak jednoznačně vyplyne $\mathrm{z}$ atributů jednotlivých procesů, tj. $\mathrm{z}$ definice elementárních činností a provázaností těchto činností s jednoznačnou definicí požadavků na kompetence zaměstnanců.

Následující výčet procesů vychází z osobních zkušeností a z ústních sdělení členů rady Sdružení knihoven, kde autorka působí jako předsedkyně.

Obrázek 1 je prríkladem stromové struktury procesů krajské vědecké knihovny. Na druhé úrovni řízení je uveden soubor klíčových procesů s tím, že na nižších stupních řízení je pro ilustraci dále rozveden vždy jen jeden ze subprocesů. 
Obrázek 1: Př́iklad stromové struktury procesů krajské vědecké knihovny

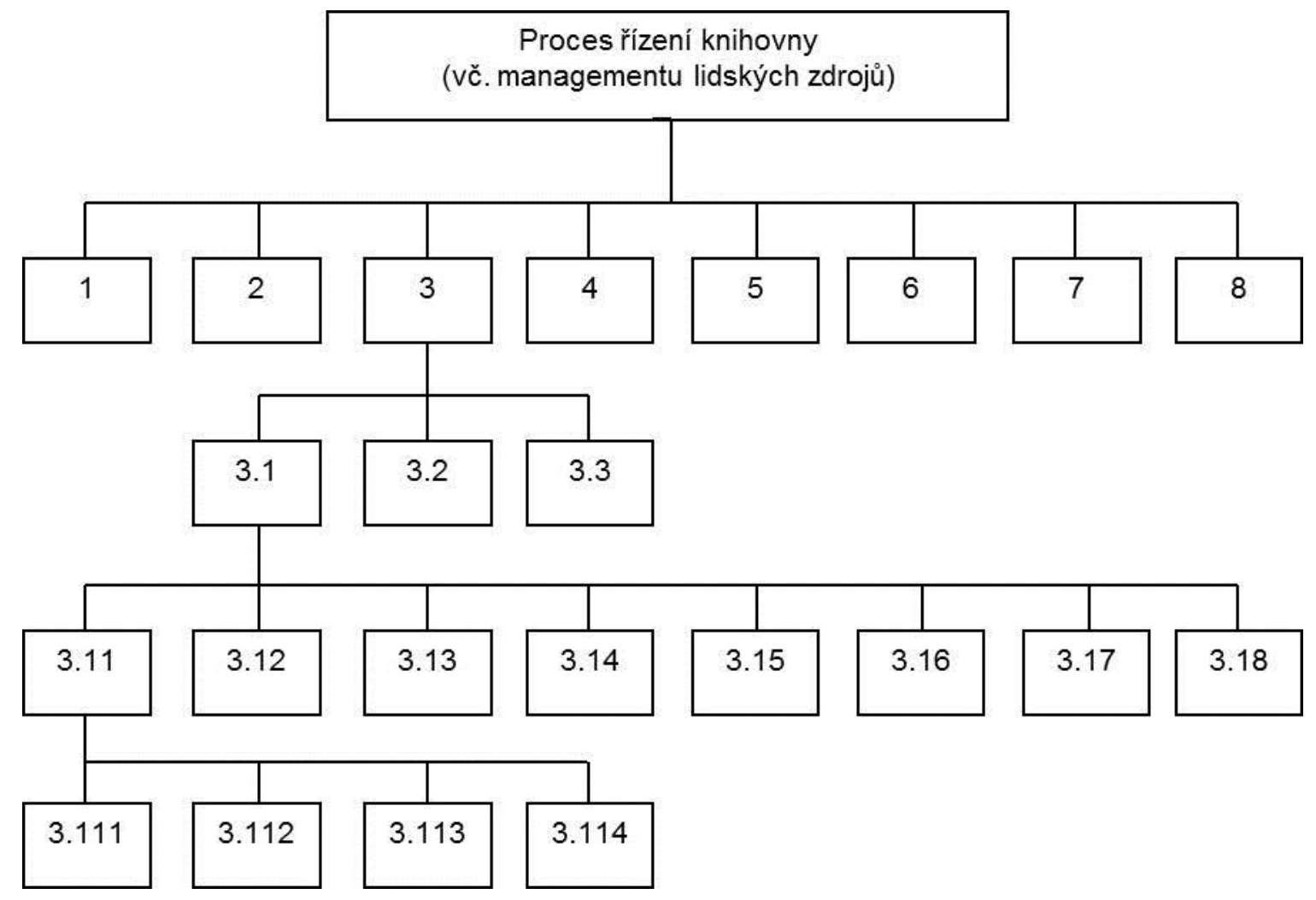

Zdroj: vlastní zpracování

Legenda:

1 Proces ř́zení lidských zdrojů

2 Proces ekonomiky a provozu

3 Proces zajišt'ování informačních zdrojů

4 Proces bibliografických aktivit

5 Proces ochrany knihovního fondu

6 Proces služeb uživatelům (mimo knihovny)

7 Proces služeb knihovnám

8 Proces vztahů $\mathrm{k}$ veřejnosti

3.1 Proces doplňování knihovního fondu

3.2 Proces zajišt'ování vzdálených elektronických zdrojů

3.3 Proces správy výměnného fondu

3.11 Proces doplňování monografií

3.12 Proces doplňování seriálů

3.13 Proces doplňování kartografických dokumenti̊

3.14 Proces doplňování hudebnin

3.15 Proces doplňování zvukových záznamů

3.16 Proces doplňování elektronických dokumentů

3.17 Proces doplňování obrazově-zvukových dokumentı̊

3.18 Proces doplňování speciálního fondu (např. dokumentů v Braillově písmu)

3.111 Proces získávání povinných výtisků

3.112 Proces nákupu monografí́

3.113 Proces získávání náhrady za ztracené a poškozené monografie

3.114 Proces adjustace monografíi (označení vlastnictvím, ochrannými a identifikačními ukazateli) 
V následující části je zvolen jeden z procesů (č. 3.1), na kterém jsou ilustrativně dokumentovány základní atributy libovolného procesu. Zde uvedené atributy slouží pouze jako př́klad co do názvi̊ činností, jejich počtu, vazeb mezi nimi i co do konkrétních parametrů, např. hodnoty regulačních a tolerančních mezí. Při realizaci daného procesu v konkrétní knihovně je plnou odpovědností managementu, tj. vlastníka procesu, jak bude proces definovat.

Proces doplňování monografií publikovaných v ČR

Cíl (požadavek): soubor monografií doplněných do knihovního fondu.

Vlastníkem procesu je zpravidla vedoucí oddělení akvizice knihovního fondu, který nese odpovědnost za dostatečnou míru splnění cíle.

V procesu doplňování monografií figurují následující atributy.

Vstupy:

- Finanční zdroje.

- Lidské zdroje - kvalifikovaní knihovníci.

- Akviziční zdroje, tj. informační zdroje o vycházejících a dostupných titulech na knižním trhu - především katalogy a databáze nakladatelství, knihkupectví včetně antikvariátu anebo knižních distributorů (v tištěné i elektronické formě, včetně elektronických knihkupectví), ediční plány nakladatelství, books in print, webové stránky nakladatelství, evidence agentur ISBN.

- Hardware.

- Knihovnický software pro objednávky a komunikaci s dodavateli a prvotní evidenci monografií.

- Legislativní dokumenty (zejména knihovní zákon a zákon o neperiodických publikacích) a řídicí dokumentace knihovny (zejména směrnice o doplňování a uchovávání knihovního fondu).

Výstupy:

- Monografie opatřené identifikátory označující vlastnictví dokumentu - vždy př́růstkové číslo, volitelně Ex Libris, ochranné prvky - čipy, elektromagnetické pásky, prvky pro automatizovanou výpůjčku - čipy nebo čárové kódy, přidělení signatury (pro umístění publikace).

- Základní záznamy evidující dokumenty v katalogu knihovny.

Řídicí veličina: monografie doplněné do knihovního fondu
Optimálni hodnota veličiny:
16.000 monografií (k. j.)/rok

Optimální hodnota vychází z počtu titulů naučné literatury vydané v roce 2012 , kde bylo se zohledněním směrnice o doplňování stanoveno 40 \% duplikátů. Hodnota 16.000 zahrnuje rovněž povinné výtisky.

Horni tolerančni mez: $\quad 18.000$ (k. j.), $+12,5 \%$

(Její dosažení by znamenalo přečerpání vymezených finančních zdrojů a hraničilo by s nedodržením rozpočtové kázně.)

Horní mez významnosti (zásahu, regulace): 17.000 (k. j.), + $6 \%$

Dolni toleranční mez:

13.700 (k. j.), $-14 \%$

(Tato hodnota by znamenala ohrožení kvalitního doplňování knihovního fondu, významné zhoršení služeb veřejnosti a v důsledku zvýšení míry rizika ohrožení dobré pověsti knihovny.)

Dolní mez významnosti (zásahu, regulace): 14.500 (k. j.), - $9 \%$

(Dosažení této meze již vyžaduje řídící zásah, v týdenním průměru se jedná o rozdíl 29 publikací proti optimální hodnotě. Pro srovnání; jde o větší počet, než zpracuje 1 knihovník za 8 hodin.) 
Doplňování monografií zahrnuje tyto činnosti a subprocesy:

- Sledování akvizičních zdrojů o regionálních monografiích, urgence nedodaných povinných výtisků, fyzická přejímka publikací, jejich zaevidování do knihovního fondu. Ošetřeno v subprocesu 3.111.

- Sledování nabídky nových titulů se zohledněním směrnice o doplňování, sledování nabídky antikvariátu pro nákup starých regionálních dokumentů, objednávání monografií a zavedení prvotních údajů do knihovnického software nebo př́mý nákup literatury, případná urgence nedodaných monografií, fyzická přejímka publikací, jejich zaevidování do knihovního fondu a prŕíprava podkladů účtárně. Ošetřeno v subprocesu 3.112.

- Analýza požadavků na obnovu poškozených a ztracených publikací, průzkum jejich dostupnosti na knižním trhu a objednání nebo výpůjčky těchto dokumentů v knihovnách, jejich kopírování, zaevidování do knihovního fondu. Ošetřeno v subprocesu 3.113.

- Označení publikací identifikačními a ochrannými údaji, př́p. fyzická jejich úprava, např. zpevnění hřbetu nebo obalení do fólie. Ošetřeno v subprocesu 3.114.

Kontrola procesu doplňování monografií spočívá $\mathrm{v}$ měsíčním vyhodnocování výkonů s ohledem na optimální hodnotu doplňovaných monografií. Řídicí zásah nastává při překročení mezí významnosti.

Řídicí zákroky při podkročení dolní meze:

- Důslednější sledování nových nabídek.

- Kontrola rozsahu objednávek.

- Rychlé a důsledné upomínání nedodaných publikací, prŕíp. jednání s regionálními vydavateli.

- Urgence nedodaných objednaných publikací a případně změna distributora.

- Analýza počtu přítomných knihovníků (nemocenské, dovolené, jiné absence), př́íp. dočasné posílení na úseku doplňování a zpracování knihovního fondu, které může být zajištěno dočasným utlumením některého z jiných procesů, např. digitalizace starých fondů nebo pořizování retrospektivních bibliografických záznamů. Předpokladem je průběžné vzdělávání pracovníků k výkonu činností v rámci několika procesů.

- Sledování výkonnosti knihovníků, analýza výkyvů v rychlosti práce. Zlepšení možné proškolením, výměnou techniky, upgradem softwaru.

Ř́idicí zákroky při překročení horní meze

- Kontrola kvality práce knihovníků.

- Př́ísné sledování finančních zdrojů na nákup.

- Odhad vývoje doplňování pro příští období, a to na základě analýzy struktury knižního trhu ve srovnání s požadavky uživatelů, dále se zohledněním průměrné ceny knihy a poměru vydávaných elektronických a tištěných knih či vývoje počtu regionálních publikací, které krajské knihovny získávají díky právu povinného výtisku (Zpráva o českém knižním trhu, 2013). Pro odhad je také nutno znát sazbu DPH, výši očekávané státní podpory, která je poskytována na nákup původní české literatury v programu Ministerstva kultury Česká knihovna, příp. možnost získávání dalších dotací nebo př́imo darů publikací. 


\section{Závěr}

Cílem článku bylo zmapování povědomí o procesním př́istupu v řízení krajských knihoven a zahájení přípravy návrhu metodiky. Tento cíl byl splněn a $\mathrm{v}$ další práci se předpokládá rozpracování metodiky k realizaci procesního ř́zení v krajských knihovnách.

Návrh metodiky bude rozdělen do tř́ fází:

- identifikace požadavků zainteresovaných stran,

- volba modelu realizace,

- aplikace modelu v praxi, posouzení míry shody či neshody plánovaného modelu s realitou.

V první fázi je zapotřebí pečlivě analyzovat požadavky zainteresovaných stran, tj. uživatelů knihovny, zřizovatele, zaměstnanců, dodavatelů a legislativního rámce. Důkladná znalost požadavků uživatelů by měla vycházet $\mathrm{z}$ průzkumu prostředí, v němž knihovna působí, měla by reflektovat existenci vzdělávacích subjektů a dalších informačních institucí a znát nedostatky v nabídce kulturních a vzdělávacích služeb. Požadavky zřizovatele jsou především stanoveny ve zřizovací listině, průběžně však jsou doplňovány a aktualizovány. Zaměstnanci mají své požadavky zakotveny v pracovních smlouvách a v případě existence odborových organizací také ve smlouvách kolektivních. Největší rozptyl patrně nastává v požadavcích dodavatelů, nebot' tito zajišt'ují široké spektrum zdrojů - materiálu a služeb včetně napřr. zajišt'ování prostor k činnosti knihovny. Všichni mají své požadavky, přičemž požadavky mezi skupinami a často i v rámci skupin zainteresovaných stran jsou protichůdné. Knihovna je zde proto, aby požadavky naplňovala $v$ dostatečné míře, tj. aby její služby byly dostatečně kvalitní.

Ve druhém kroku je nutno zvolit model realizace, kterým mohou být požadavky norem ISO řady 9000 a 9001, podle nichž bude knihovna strukturována a ř́zena. Zapotřebí je rovněž specifikovat zdroje nutné $\mathrm{k}$ realizaci. Aplikace modelu musí být managementem zrretelně podporována a na všech úrovních rrízení důsledně vyžadována.

Výsledkem třetí fáze realizace metodiky procesního modelu řízení je míra shody či neshody $\mathrm{s}$ realitou a specifikace souhrnu potřebných změn. Z praktických zkušeností jiných firem se změny dají očekávat v následujících oblastech:

- $\quad \mathrm{v}$ problematice identifikace elementárních činností a s tím spojených požadovaných kompetenčních požadavků,

- v zajištění naplnění kompetenčních požadavků,

- v problematice řízení interní a externí dokumentace,

- v oblasti interních auditů a vyhodnocování stanovených metrik,

- v aplikaci efektivní týmové práce a dalších metodách managementu změny,

- v pravidelném přezkoumávání efektivního systému řízení vrcholovým managementem knihovny.

\section{Literatura}

[1] Audit jakosti: obecné základy, 1998. 1. vyd. Praha: Česká společnost pro jakost. ISBN 80-02-01261-5.

[2] BHATT, S., 2012. Total Quality Management: an Effecftive Approach for Library System. International Journal of Information Dissemination and Technology, 2(4), 266269. ISSN 2229-5984. 
[3] BUSCH, R., 2008. BibliotheksManagement als Chance. BuB: Forum Bibliothek und Information, 60(10), s. 726. ISSN 1869-1137. Dostupný též z: http://www.svkos.cz (databáze EBSCO: Academic Search Complete).

[4] ČSN EN ISO 9000. Systémy managementu kvality: základní principy a slovník, 2006. Praha: Český normalizační institut.

[5] ČSN EN ISO 9001. Systémy managementu kvality: požadavky, 2010. Praha: Český normalizační institut.

[6] GRASSEOVÁ, M., R. DUBEC a R. HORÁK, 2008. Procesní řízení ve veřejném sektoru: teoretická východiska a praktické př́klady. Vydání první. Praha: Computer Press. ISBN 978-80-251-1987-7.

[7] G-8DReport 2013. Palstat Vrchlabi [online]. [cit. 18. června 2013]. Dostupný z: http://www.wabashtech.com/content/PDF/F14-01-000A.pdf

[8] LAUGHLIN, S. a R. W. WILSON, 2008. The Quality Library: a Guide to SelfImprovement, Better Efficiency, and Happier Customers. Chicago: American Library Association. ISBN 978-0-8389-0952-2.

[9] PINTOZZI, CH., 2014. The Implementation and Evolution of Quality Management in the University of Arizona Libraries. In: S. A. MURPHY, ed. The Quality Infrastructure: Measuring, Analyzing, and Improving Library Services. Chicago: American Library Association, s. 41-57. ISBN 978-0-8389-1173-0.

[10] Standard pro dobrou knihovnu: metodický pokyn Ministerstva kultury k vymezení standardu veřejných knihovnických a informačních služeb poskytovaných knihovnami zřizovanými a/nebo provozovanými obcemi a kraji na území České republiky, 2013. Praha: Národní knihovna České republiky. ISBN 978-80-7050-628-8.

[11] VESELÝ, J., L. ČERNOHORSKÁ, T. KUBALA a P. JUŘICA, 2013. The Contribution of Measurment Processes in a Time of Economic Crisis. Acta academica karviniensia [online]. 13(2), 158-168 [cit. 15. září 2013]. ISSN 1212-415X. Dostupné z: http://www.slu.cz/opf/cz/informace/acta-academica-karviniensia/casopisy-aak/aakrocnik-2013/acta-academica-karviniensia-2-2013

[12] Zlepšování organizací veřejného sektoru prostřednictvím sebehodnocení: CAF 2013, 2013. Praha: Národní informační středisko podpory kvality [online]. [cit. 9. června 2014]. ISBN 978-80-02-02472-9. Dostupné z: http://www.npj.cz/tmce/ Obrazky\%20aktuality/93.pdf

[13] Zpráva o českém knižním trhu 2012/2013, 2013. Praha: Svaz českých knihkupců a nakladatelů [online]. [cit. 2. ř́́jna 2013]. ISBN 978-80-902495-8-5. Dostupné z: http://sckn.cz/content/zpravy/file-936.pdf 